\title{
ANALISIS SEMIOTIK DALAM KUMPULAN SAJAK KETIKA JARUM JAM LELEH DAN LELAH BERDETAK KARYA DIMAS ARIKA MIHARDJA
}

\author{
Jetri Ramasyahri ${ }^{1}$, Sumiharti ${ }^{2}$, Erlina Zahar $^{3}$ \\ Program Studi Pendidikan Bahasa dan Sastra Indonesia, \\ Fakultas Keguruan dan Ilmu Pendidikan, Universitas Batanghari, \\ Jambi \\ Jetri.ramasyahri96@yahoo.com \\ harti.sumi@yahoo.com \\ erlina_zahar@yahoo.com
}

\begin{abstract}
This research is aimed at describing the use of semiotic in Ketika Jarum Jam Leleh dan Lelah Berdetak anthology by Dimas Arika Mihardja. This research identifies the signs of meaning and interpretations towards hermeneutics approach. This research is descriptive qualitative. The population of the research is the verses in Ketika Jarum Jam Leleh dan Lelah Berdetak anthology by Dimas Arika Mihardja. In collecting the data, purposive sampling is used. The primary data is taken from verbal data in a form of words in Ketika Jarum Jam Leleh dan Lelah Berdetak anthology by Dimas Arika Mihardja, while secondary data is taken from semiotic theory and some literary books. Based on the result and discussion, it can be concluded that there are signs in Ketika Jarum Jam Leleh dan Lelah Berdetak by Dimas Arika Mihardja, they are Penikmat kehidupan anthology, they are; human being who lives in this world. Human being who are full of story, human being who wants to live happily by having the freedom whithout thinking about the consequences are ended up being despicable. Being despicable with what they have done is useless that leads them to feel regret.
\end{abstract}

Key Words: semiotic, hermeneutic, anthology.

\footnotetext{
${ }^{1}$ Mahasiswa Program Studi Pendidikan Bahasa dan Sastra Indonesia, Fakultas Keguruan dan Ilmu Pendidikan, Universitas Batanghari, Jambi

${ }^{2}$ Dosen Program Studi Pendidikan Bahasa dan Sastra Indonesia, Fakultas Keguruan dan Ilmu Pendidikan, Universitas Batanghari ,Jambi

${ }^{3}$ Dosen Program Studi Pendidikan Bahasa dan Sastra Indonesia, Fakultas Keguruan dan Ilmu Pendidikan, Universitas Batanghari, Jambi
} 


\section{PENDAHULUAN}

Karya sastra merupakan salah satu alat pemuas kebutuhan akan nilai keindahan. Keindahan ini dapat dinikmati dengan berbagai cara, misalnya melihat, mendengar, atau membaca karya sastra. Karya sastra yang memiliki keindahan akan memberikan pengetahuan serta nilai positif bagi pembaca. Hal ini membuat karya sastra banyak diminati oleh semua kalangan masyarakat. Karya sastra beragam bentuknya antara lain novel, drama, cerpen, puisi, dan sajak.

Secara garis besar sastra bergerak pada empat paradigma yaitu penulisan karya, pembaca, kenyataan dan semesta. Untuk memenuhi keempat paradigma tersebut, maka diciptakan teori-teori tentang karya sastra. Satu diantara teori tersebut adalah teori semiotik.

Semiotik adalah sebuah teori dan pendekatan dalam sastra yang memandang karya sastra sebagai struktur tanda yang bermakna. Lambang-lambang atau tandatanda kebahasaan itu berupa satuan-satuan bunyi yang mempunyai arti.

Semiotika atau semiologi berasal dari bahasa Yunani, yaitu semeion yang berarti tanda atau seme yang berarti penafsiran. Dalam kehidupan sehari-hari sebenarnya manusia juga sering berada dalam proses semiosis, yaitu memahami sesuatu yang ada di sekitarnya sebagai sistem tanda. Ketika kita melihat langit yang mendung, misalnya maka orang akan mengatakan bahwa sebentar lagi hujan akan turun. Demikian juga ketika suatu hari tampak beberapa orang memakai baju warna hitam, yang kemudian ditafsirkan sebagai para pelayat yang sedang berada dalam suasana duka.

Peletakkan dasar teori semiotika adalah, Ferdinand de Saussure di Eropa (1857-1913) dikenal sebagai bapak ilmu bahasa modern dengan dasar linguistik mengembangkan konsep semiologi dan Charles Sanders Peirce di Amerika Serikat (1834-1914) dikenal sebagai seorang ahli filsafat dengan pengertian yang sama, yaitu mengembangkan konsep semiotik. Selanjutnya baik semiologi maupun semiotika dipergunakan dengan pengertian yang sama artinya. Dalam pengkajian puisi menggunakan semiotik, terdapat dua tokoh yang menonjol dalam teori semiotik, yaitu Michael Riffaterre dan Roman Ingarden.

Sepengetahuan peneliti di lapangan belum ditemukan penelitian kajian semiotik dalam kumpulan sajak yang berjudul Ketika Jarum Jam Leleh dan Lelah Berdetak karya Dimas Arika Mihardja. Oleh karena itu, peneliti merasa tertarik menjadikan buku kumpulan sajak tersebut sebagai objek kajian penelitian. 
Peneliti menganalisis semiotik dalam sajak tersebut, karena dengan menggunakan kajian semiotik, dapat memberikan pemahaman makna yang jelas terhadap sebuah karya sastra. Peneliti memilih sajak dalam kajian penelitian ini, karena sajak lebih mengutamakan keindahan penataan unsur bunyi.

Selain itu peneliti memilih kumpulan sajak Ketika Jarum Jam Leleh dan Lelah Berdetak ini karena Dimas Arika Mihardja dikenal sebagai sastrawan Jambi. Setelah peneliti membaca ringkasan cerita yang terdapat pada bukunya, sajaksajaknya memiliki keunikan bagi peneliti. Selain itu, kumpulan sajak Ketika Jarum Jam Leleh dan Lelah Berdetak karya Dimas Arika Mihardja ini sangatlah menarik karena buku kumpulan sajak tersebut berisi sajak-sajak selama sepuluh tahun terakhir yang sudah diseleksi, maka dari itu peneliti sangat tertarik untuk mengkaji semiotik dalam kumpulan sajak Ketika Jarum Jam Leleh dan Lelah Berdetak.

Berdasarkan pendapat Riffaterre dalam bukunya Pengkajian Puisi: Analisis Strata Norma dan Analisis Stuktural dan Semiotik (dalam Pradopo, 2010:4) bahwa semiotik memiliki empat prinsip dasar dalam pemaknaan puisi yakni:

1. Ketidaklangsungan ekspresi,
2. Heuristik dan hermeneutik,

3. Matriks dan model,

4. Hipogram

Fokus masalah dalam penelitian ini adalah kajian hemeneutik dalam kumpulan sajak Ketika Jarum Jam Leleh dan Lelah Berdetak karya Dimas Arika Mihardja. Selanjutnya pertanyaan penelitian dalam penelitian ini adalah, bagaimanakah hermeneutik yang tedapat dalam kumpulan sajak Ketika Jarum Jam Leleh dan Lelah Berdetak karya Dimas Arika Mihardja?

Penelitian ini bertujuan untuk, mendeskripsikan hermeneutik yang terdapat dalam kumpulan sajak Ketika Jarum Jam Leleh dan Lelah Berdetak karya Dimas Arika Mihardja. Berdasarkan tujuan penelitian di atas, maka manfaat dalam penelitian ini dibagi menjadi dua, yaitu manfaat teoretis dan manfaat praktis.

Secara teoretis hasil penelitian ini diharapkan dapat menambah khazanah kesusastraan terutama bagaimana mengkaji sebuah karya sajak dari segi semiotik yang berkaitan dengan sistem tanda. Hasil penelitian juga dapat dijadikan sebagai rujukan atau sebagai bahan perbandingan oleh penelitian selanjutnya. Serta dapat menambah wawasan peneliti lain dalam mengkaji karya sastra berkaitan dengan kandungan makna sajak berdasarkan heuristik dan hermeneutik. 
Manfaat praktis dalam penelitian ini adalah:

1. Bagi pembaca baik mahasiswa Program Studi Pendidikan Bahasa dan Sastra Indonesia, FKIP Universitas Batanghari Jambi maupun masyarakat secara umum, hasil penelitian ini dapat menambah pengetahuan tentang sebuah karya sajak yang dikaji dari segi semiotik.

2. Bagi siswa, penelitian ini dapat menambah pengetahuan pemahaman tentang makna sajak terutama pada sistem semiotik.

3. Bagi sastrawan atau penulis, hasil penelitian ini dapat memberikan pengetahuan tentang bagaimana sebuah karya sajak dapat dikaji dalam segi semiotik.

4. Hasil penelitian ini dapat dijadikan sebagai acuan dalam melakukan penelitian lain pada aspek dan teori yang berbeda.

\section{METODE PENELITIAN}

Dalam penelitian, jenis penelitian sangatlah penting untuk mencapai tujuan yang diharapkan. Penelitian adalah cara untuk mendapatkan data yang dengan tujuan dan kegunaan tertentu. Jenis penelitian merupakan cara memahami objek yang menjadi sasaran penelitian.
Seorang peneliti dapat memilih satu dari berbagai jenis yang ada sesuai dengan tujuan penelitian. "Jenis penelitian berarti cara yang digunakan seseorang peneliti di dalam usaha memecahkan masalah yang diteliti" (Siswantoro, 2014:55).

Jenis penelitian ini adalah jenis deskriptif kualitatif, yaitu menyarankan pada kajian yang dilakukan semata-mata hanya berdasarkan pada fakta atau fenomena secara empiris, artinya yang dicatat dan dianalisis dengan menggunakan pendekatan analisis semiotik. Penelitian ini dilaksanakan di Jambi. Penelitian ini dimulai dari tanggal 15 November 2016 dan direncanakan akan berakhir pada 15 Mei 2017.

Populasi dalam penelitian ini adalah semua sajak Ketika Jarum Jam Leleh dan Lelah Berdetak karya Dimas Arika Mihardja. Sampel diambil dari populasi menggunakan purposive sampling. Purposive sampling adalah teknik pengambilan data dengan pertimbangan tertentu (Sugiyono, 2013: 218). Adapun yang menjadi sampel adalah sajak Bercinta di Padang Bunga.

Data primer dari penelitian ini adalah kata dalam kumpulan sajak Ketika Jarum Jam Leleh dan Lelah Berdetak karya Dimas Arika Mihardja yang 
berkaitan dengan pendekatan hermeneutik.

Data skunder pada penelitian ini bersumber dari data yang diperoleh dari hasil studi pustaka. Sumber pustaka yang penulis gunakan adalah teori tentang semiotik, buku-buku yang berhubungan dengan teori karya sastra, sajak, metode penelitian bahasa, metode penelitian sastra, buku penulisan karya ilmiah.

Sumber data primer penelitian ini, yakni kumpulan sajak Ketika Jarum Jam Leleh dan Lelah Berdetak karya Dimas Arika Mihardja. Kumpulan sajak ini merupakan sajak yang diciptakan oleh sastrawan Jambi, yang merupakan sajak cetakan pertama pada tahun 2003. Sajak ini terdiri dari 76 halaman yang diterbitkan oelh Bengkel Puisi Swadaya Mandiri. Berkulit sampul hitam dan bercampur sedikit keabu-abuan di atasnnya, bertuliskan angka 70 berwarna biru di belakang tulisan ketika jarum jam leleh dan lelah berdetak dengan warna putih kemudian tulisan tujuhpuluh sajak Dimas Arika Mihardja berwarna kuning. Didesain dengan berat $0,13 \mathrm{~kg}$, panjang $21 \mathrm{~cm}$ dan lebar $15 \mathrm{~cm}$.

Sumber data skunder penulis dapatkan dari berbagai perpustakaan diantaranya dari perpustakaan Universitas Batanghari Jambi, perpustakaan FKIP Universitas Batanghari Jambi, perpustakaan wilayah, maupun perpustakaan kota, meminjam dari dosen maupun dari teman.

Teknik pengumpulan data dalam penelitian ini menggunakan studi pustaka yang difokuskan dalam analisis semiotik dalam kumpulan sajak Ketika Jarum Jam Leleh dan Lelah Berdetak karya Dimas Arika Mihardja. Langkah-langkah pengumpulan data dalam penelitian ini dijelaskan sebagai berikut:

1. Membaca secara keseluruhan sajaksajak yang terdapat dalam kumpulan sajak Ketika Jarum Jam Leleh dan Lelah Berdetak karya Dimas Arika Mihardja dengan teliti, kritis, dan berulang-ulang. Hal ini, bertujuan untuk mencermati dengan tepat sistem tanda yang terdapat dalam teks-teks tersebut.

2. Menetukan lima belas judul sajak yang dijadikan sebagai bahan kajian.

3. Dari lima belas sajak tersebut ditandai bagian-bagian sajak yang berupa satuan semiotik yang berhubungan dengan sistem tanda.

4. Mengiventarisasikan bagian-bagian sajak yang berupa satuan semiotik yang berhubungan dengan bentuk sistem tanda yang sesuai dengan bahan kajian hermeneutik.

5. Mengelompokkan data yang sudah terkumpul sesuai permasalahan. 
Teknik analisis data dalam penelitian ini dilakukan dengan cara sebagai berikut:

1. Data yang sudah dikelompokkan berdasarkan aspek-aspek yang diteliti, ditabulasi data dipindahkan dalam tabel tabulasi data.

2. Data dianalsis sesuai dengan kerangka teori yang berkaitan dengan masalah penelitian.

3. Data yang sudah dianalisis, selanjutnya diinterpretasi sesuai dengan kerangka teori secara jelas dan terperinci.

4. Penarikan kesimpulan.

Triangaulasi dilakukan untuk mendapatkan kesahihan hasil sebuah penelitian. Untuk mengetahui kebenaran dan keakuratan data yang diperoleh dalam penelitian ini, dilakukan pemeriksaan kesahihan. Triangulasi yang dilakukan dalam penelitian ini adalah triangulasi personal (informan) yang dilakukan dengan cara mengecek, mengevaluasi, dan mendiskusikan data dengan informan dan pembimbing.

\section{HASIL DAN PEMBAHASAN}

Dalam pendekatan hermeneutik, peneliti menginterpretasikan makna secara utuh dan menjelaskan makna yang ada dalam suatu sajak atau menafsirkan secara langsung teks-teks sajak yang terdapat dalam kumpulan sajak Ketika Jarum Jam
Leleh dan Lelah Berdetak karya Dimas Arika Mihardja.

Berdasarkan analisis semiotik dengan menggunakan pendekatan hermeneutik pada sajak yang berjudul Perambah Hutan di atas, ditemukan enam tanda pada bait pertama, dan empat tanda pada bait kedua yang diuraikan sebagai berikut:

Bait ke - 1

1. Perambah memberikan tanda yang artinya, penikmat.

2. Hutan memberikan tanda yang artinya, kehidupan.

3. Berpesta memberikan tanda yang artinya, bersenang-senang.

4. Menista memberikan tanda yang artinya, merasa hina.

5. Menderita memberikan tanda yang artinya, dengan penuh rasa penyesalan.

6. Peta memberikan tanda yang artinya, perintah.

Bait ke - 2

1. Perambah memberikan tanda yang artinya, penikmat.

2. Hutan memberikan tanda yang artinya, kehidupan.

3. Tersuruk memberikan tanda yang artinya, terjatuh. 
4. Fatamorgana memberikan tanda yang artinya, tipu daya.

5. Mengeja memberikan tanda yang artinya, mengucapkan.

Setelah dilakukan analisis, maka didapatlah hasil atau temuan tanda-tanda yang selanjutnya penulis akan menginterpretasikan makna secara utuh dan menjelaskan makna yang ada dalam sajak tersebut dengan menggunakan pendekatan hermeneutik.

Sajak yang berjudul Perambah Hutan menggambarkan kehidupan manusia di dunia sebagai penikmat kehidupan yang tersesat karena tidak mau mengikuti petunjuk-Nya. Dan pada akhirnya manusia sadar bahwa yang dilakukannya selama ini salah dan tak ada gunanya, semua itu terjadi karena manusia tidak mensyukuri nikmat yang telah Allah berikan kepadanya. Selanjutnya, sajak tersebut, diuraikan pada bait berikut ini:

Bait ke - 1

Penikmat kehidupan ialah manusia yang hidup di dunia. Manusia yang penuh dengan cerita, manusia yang selalu ingin hidup dengan bersenang-senang hanya demi merasakan sebuah kebebasan, tanpa memikirkan akibatnya yang pada akhirnya manusialah yang merasa hina. Hina dengan perbuatan yang selama ini dilakukan ternyata itu tidak ada gunanya, hingga manusia sendirilah yang hidup dengan penuh rasa penyesalan. Sebab selama hidup di dunia, hanya digunakan untuk bersenang-senang, dan dosa semakin bertambah banyak. Hingga menyebabkan manusia tersesat di dalam gelap. Semua itu karena manusia tidak mau mengikuti perintah-Nya.

Bait ke - 2

Penikmat kehidupan ialah, manusia yang memilih berjalan dengan menutup mata hingga terjatuh dalam gemerlapnya dunia, pada akhirnya manusia pun sadar seakan Allah menunjukkan ke jalan yang benar, karena manusia yang terlalu mudah terpengaruh dalam tipu daya dunia. Itu semua terjadi karena manusia yang hidup di dunia, banyak yang lupa diri dan lupa mengucapkan syukur atas kebesarankebesaran dan nikmat yang telah Allah berikan kepadanya.

\section{SIMPULAN}

Berdasarkan hasil penelitian dan pembahasan, dapat disimpulkan bahwa dalam kumpulan sajak karya Dimas Arika Mihardja, terkandung nilai-nilai kehidupan dalam alam sekitar. Penulis dapat memberikan penafsiran dan pemaknaan berdasarkan pendekatan hermeneutik yang 
terdapat dalam kumpulan sajak Ketika karya Dimas Arika Mihardja adalah sebagai berikut:

Sajak yang berjudul Perambah Hutan, terdapat tanda-tanda berdasarkan pendekatan hermeneutik yaitu, perambah, hutan, berpesta, menista, menderita, peta, tersuruk, fatamorgana, mengeja. Maka, dapatlah ditafsirkan yaitu, kehidupan manusia di dunia sebagai penikmat kehidupan yang tersesat karena tidak mau mengikuti petunjuk-Nya, hingga manusia sendirilah nanti yang hidup dengan penuh rasa penyesalan.
Jarum Jam Leleh dan Lelah Berdetak.

\section{DAFTAR PUSTAKA}

Pradopo, Rahmat Djoko. (2010). Pengkajian Puisi: Analisis Strata Norma dan Analisis Struktual dan Semiotik. Yogyakarta: Gajah Mada University Press.

Siswantoro. (2010). Metode Penelitian Sastra Analisis Struktur Puisi. Yogyakarta: Pustaka Belajar.

Sugiyono. (2013). Metode Penelitian Pendidikan (Pendekatan Kuantitatif, Kualitatif, dan $R \& D)$. Bandung: Alfabeta. 